\title{
PENGARUH PERINGKAT OBLIGASI DAN KONFLIK BONDHOLDER- SHAREHOLDER TERHADAP PENERAPAN KONSERVATISME AKUNTANSI
}

\author{
Mailiza Maharani1, Agrianti Komalasari2, Komaruddin3 \\ ${ }^{1}$ Fakultas Ekonomi dan Bisnis, Universitas Lampung \\ ${ }^{2}$ Fakultas Ekonomi dan Bisnis, Universitas Lampung \\ 3 Fakultas Ekonomi dan Bisnis, Universitas Lampung
}

\section{Informasi Naskah}

Update Naskah:

Dikumpulkan: 2 Dec 2020;

Diterima: 4 January 2021;

Terbit/Dicetak: 24 January 2021.

\section{Keywords:}

Bond Rating, Bondholder-

Shareholder Conflicts, Accounting

Conservatism.

\section{$\underline{\text { Abstract }}$}

This research is a research using quantitative analysis that aims to know the influence of bond rating and bondholdershareholder conflicts to accounting conservatism implementation in non finance and banking companies that listed in the Indonesian Stock Exchange (IDX) in 2011-2018. The data which is used in this research is secondary data obtained from company's annual report in Indonesian Stock Exchange (IDX). The samples of this research obtained by using purposive sampling method. Based on this criteria, obtained 33 companies as sample of this research. Analysis method which is used is the multiple regressions analysis. The result of this research indicate that bond rating and bondholder-shareholder conflict have no significant effect on accounting conservatism implementation. 


\section{A. PENDAHULUAN}

Dalam aktivitasnya, investasi terbagi menjadi dua bentuk, yaitu real investment dan financial investment. Real investment merupakan investasi nyata yang secara umum melibatkan aset berwujud, seperti tanah, mesin-mesin atau pabrik, sedangkan financial investment merupakan investasi keuangan yang melibatkan kontrak tertulis, seperti saham biasa dan obligasi. Dan investasi langsung yang biasa dapat diperjualkan dalam pasar modal yaitu investasi obligasi (Fahmi, 2013).

Dalam investasi obligasi, perusahaan yang menerbitkan obligasi mempunyai kewajiban untuk membayar bunga secara regular sesuai dengan jangka waktu yang telah ditetapkan serta pokok pinjaman pada saat jatuh tempo. Pembayaran bunga obligasi dapat mengakibatkan perubahan peringkat obligasi. Perubahan ini mengakibatkan adanya kemungkinan risiko gagal bayar yang merupakan risiko kerugian yang mungkin terjadi yang disebabkan oleh lemahnya kemampuan emiten dalam membayar bunga dan pinjaman pokok obligasi, sedangkan perubahan peringkat obligasi menjadi salah satu faktor yang memengaruhi arah investasi dan menjadi pertimbangan investor dalam berinvestasi di perusahaan. Oleh karena itu, peringkat obligasi dapat dikatakan sebagai indikator risiko gagal bayar obligasi. Jika terjadi penurunan peringkat obligasi atau mendapat peringatan penurunan peringkat maka perusahaan akan meninjau kembali beberapa kebijakannya, misalnya utang yang semakin naik harus ditahan. Dengan demikian, perusahaan akan menerapkan konservatisme akuntansi untuk memperkuat laporan keuangan sehingga terhindar dari kerugian yang besar dimasa mendatang.

Selain peringkat obligasi, dalam transaksi di pasar modal juga kerap terdapat konflik bondholdershareholder. Shareholder menuntut perusahaan membagikan dividen yang tinggi sebagai hasil dari investasi, sedangkan, bondholder menuntut perusahaan untuk tidak membayarkan dividen berlebihan agar tersedia jaminan atau aset cukup untuk pembayaran utang. Kondisi tersebut menyebabkan bondholder kehilangan jaminan pelunasan utang yang berpotensi meningkatkan risiko tidak terbayar sehingga akan meningkatkan potensi konflik bondholder-shareholder, maka perusahaan akan menerapkan konservatisme akuntansi untuk mencegah kerugian yang berlebih.

Dalam penelitian terdahulu, masih terdapat perbedaan hasil penelitian. Hasil penelitian Ulfa et al. (2018) menyatakan konflik bondholder-shareholder berpengaruh positif pada konservatisme akuntansi, sedangkan hasil penelitian Novita (2017) menyatakan konflik bondholder-shareholder berpengaruh negatif terhadap konservatisme akuntansi. Akibat masih adanya perbedaan hasil penelitian, maka penelitian ini bertujuan untuk: (1) Mengetahui pengaruh peringkat obligasi terhadap penerapan konservatisme akuntansi; (2) Mengetahui pengaruh konflik bondholder-shareholder terhadap penerapan konservatisme akuntansi.

\section{B. LANDASAN TEORI DAN PENGEMBANGAN HIPOTESIS}

\section{Agency Theory}

Teori keagenan merupakan teori ketidaksamaan kepentingan antara principal dan agent (Jensen dan Meckling, 1976). The agency theory memberikan fokus terhadap fakta yang berkembang bahwa dalam setiap organisasi individu yang disebut the agentakan bertindak sebagai pihak yang dipercaya oleh individu atau sekelompok individu lainnya yang disebut the principal. Para ahli agency theory menggunakan asumsi bahwa kedua pihak baik agent maupun principal memiliki kepentingan masing-masing dan kepentingan tersebut lebih banyak mengalami perbedaan dari sudut pandang keduanya. Dalam kaitan ini para ahli berkeyakinan bahwa keberadaan struktur organisasi merupakan upaya rasional yang digunakan, walaupun bersifat kompleks tetapi mampu menciptakan sistem yang efisien di dalam mengatur kerja sama antara kedua pihak yang berhubungan (Lukviarman, 2016). 


\section{Signaling Theory}

Teori signal menjelaskan mengapa perusahaan mempunyai dorongan untuk memberikan informasi laporan keuangan kepada pihak eksternal. Kurangnya informasi yang diperoleh pihak luar tentang perusahaan menyebabkan pihak luar melindungi diri dengan memberikan nilai rendah untuk perusahaan tersebut. Perusahaan dapat meningkatkan nilai perusahaan dengan menggunakan menggunakan informasi asimetris, salah satunya dengan memberi signal kepada pihak luar berupa informasi keuangan yang dapat dipercaya sehingga dapat mengurangi ketidakpastian mengenai prospek perusahaan pada masa yang akan datang (Sari, 2006).

\section{Konservatisme Akuntansi}

Konservatisme merupakan prinsip kehati-hatian dalam pelaporan keuangan yang dalam hal ini perusahaan tidak terburu-buru dalam mengakui dan mengukur aset dan laba serta mengakui kerugian dan hutang yang mempunyai kemungkinan yang terjadi (Watts, 2006). Dan menurut Glosarium Pernyataan Konsep No. 2 FASB, konservatisme diartikan sebagai reaksi yang hati-hati dalam menghadapi ketidakpastian yang melekat pada perusahaan untuk mencoba memastikan bahwa ketidakpastian dan risiko dalam lingkungan bisnis yang sudah cukup dipertimbangkan (Savitri, 2016).

\section{Konflik Bondholder-Shareholder}

Terdapat berbagai macam masalah yang menimbulkan konflik bondholder-shareholder di antaranya yaitu masalah underinvestment, masalah penggantian aset, masalah penerbitan hutang baru dan masalah kebijakan dividen atau pada saat perusahaan mencari pendanaan dari hutang. Semakin besar bondholder melakukan klaim atas aset perusahaan, maka semakin besar pula hutang perusahaan (Ulfa etal. ,2018). Konflik bondholder-shareholder terjadi karena perbedaan kepentingan mengenai kebijakan pembayaran dividen akibat adanya pendanaan investasi dari hutang. Bondholder meminta perusahaan untuk tidak membayarkan dividen berlebih agar tersedia kecukupan aset minimum untuk pembayaran hutang, sedangkanshareholder menuntut adanya pembayaran dividen terus menerus dan jumlahnya besar(Sari, 2004). Dan juga dalam konflik bondholder-shareholder, diasumsikan shareholder memilih dan mengangkat, mengompensasi dan memecat manajer, sehingga dianggap efisien yang menyamakan tujuan manajer dengan pemegang saham (Nasih dan Hudaya, 2011).

\section{Peringkat Obligasi}

Peringkat obligasi menggambarkan pada credible dan prospek layaknya obligasi tersebut dibeli untuk dijadikan sebagai salah satu current asset perusahaan (Fahmi, 2014). Peringkat obligasi juga merupakan indikator penting mengenai kualitas kredit perusahaan dan skala risiko dari semua obligasi yang diperdagangkan (Veronica, 2015).

Berdasarkan pada teori tersebut, maka dapat dikembangkan rumusan hipotesis sebagai berikut:

\section{H1: Peringkat obligasi berpengaruh negatif terhadap penerapan konservatisme akuntansi. \\ H2: Konflik bondholder-shareholder berpengaruh positif terhadap penerapan konservatisme akuntansi.}

\section{METODE PENELITIAN}

\section{Populasi dan Sampel}

Populasi yang digunakan dalam penelitian ini yaitu perusahaan nonkeuangan dan perbankan yang terdaftar di Bursa Efek Indonesia tahun 2011-2018. Metode pengambilan sampel yang digunakan dalam penelitian ini adalah metode purposive sampling. Dalam penelitian ini, objek yang menjadi sampel adalah perusahaan non keuangan dan perbankan yang terperingkat oleh Pefindo tahun 2011-2018 dan secara rutin mendaftarkan obligasinya. 


\section{Jenis dan Sumber Data}

Jenis data yang digunakan dalam penelitian ini yaitu data sekunder. Data sekunder yang diambil berupa data laporan keuangan tahunan tahun 2011-2018 dari situs resmi Bursa Efek Indonesia maupun situs resmi perusahaan dan data peringkat obligasi perusahaan dari situs resmi Pefindo.

\section{Variabel Penelitian}

\section{Variabel Dependen}

Dalam penelitian ini, variabel yang digunakan yaitu konservatisme akuntansi. Givoly dan Hayn (2000) memfokuskan efek konservatisme pada laporan laba rugi selama beberapa tahun dan menghasilkan akrual negatif yang terus menerus. Akrual yang dimaksud adalah perbedaan antara laba bersih sebelum depresiasi atau amortisasi dan arus kegiatan operasi. Semakin besar akrual negatif, maka akan semakin konservatif akuntansi yang diterapkan. Konservatisme diukur dengan rumus sebagai berikut:

CONACC $=\frac{(\mathrm{NIO}+\mathrm{DEP}-\mathrm{CFO}) \times(-1)}{\mathrm{TA}}$

Keterangan:

CONACC : Konservatisme akuntansi.

NIO : Laba bersih operasi.

DEP : Depresiasi atau penyusutan.

CFO : Arus kas operasi.

TA :Total aset.

\section{Variabel Independen}

\section{Peringkat Obligasi}

Peringkat obligasi diukur dengan menggunakan variabel dummy. Menurut Pefindo, perusahaan dengan kategori investment grade (AAA, $\mathrm{AA}, \mathrm{A})$ diberi nilai 1 sedangkan non investment grade $(\mathrm{BBB}, \mathrm{BB}$, B, CCC, D) diberi nilai 0 (Septyawanti, 2013).

\section{Konflik Bondholder-Shareholder}

Pengukuran besarnya konflik bondholder-shareholder dapat dilihat dari besarnya hutang perusahaan. Semakin besar hutang perusahaan, maka semakin besar pula klaim bondholder atas aset perusahaan dan meningkatkan konflik kepentingan dengan shareholder sehingga konflik bondholdershareholder pun semakin tinggi. Konflik bondholder-shareholder diukur menggunakan leverage dengan rumus sebagai berikut (Ahmed et al. , 2002):

Tingkat Pembayaran Hutang $=\frac{\text { Total Hutang }}{\text { Total Aset Perusahaan }} \times 100 \%$

\section{Metode Analisis Data}

Teknik analisis data yang digunakan dalam penelitian ini adalah menggunakan uji statistik menggunakan aplikasi SPSS 26. Uji statistik yang digunakan yaitu uji statistik deskriptif, uji asumsi klasik, dan uji hipotesis. Adapun analisis regresi berganda dilakukan untuk menguji pengaruh lebih dari satu variabel independen terhadap variabel dependen. Dalam penelitian ini diperoleh persamaan model regresi berganda sebagai berikut:

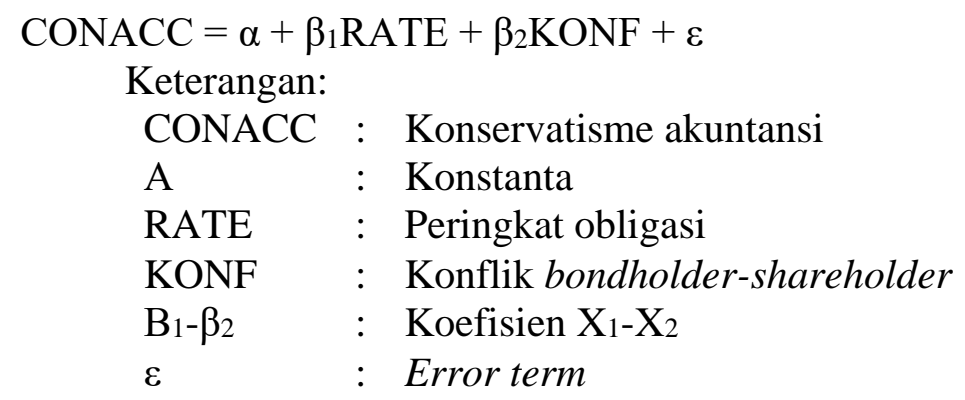




\section{ANALISIS DAN PEMBAHASAN}

\section{Gambaran Umum Objek Penelitian}

Penelitian ini menggunakan objek penelitian yaitu perusahaan non keuangan dan perbankan yang terdaftar di Bursa Efek Indonesia dari tahun 2011-2018. Sebanyak 622 perusahaan yang terdaftar di Bursa Efek Indonesia dinyatakan sebagai populasi. Sejumlah kriteria telah ditetapkan dalam pemilihan sampel. Berdasarkan kriteria tersebut, diperoleh sebanyak 33 perusahaan sebagai sampel penelitian.

\section{Uji Statistik Deskriptif}

Hasil uji statistik deskriptif data regresi berganda antara variabel peringkat obligasi dan konflik bondholder-shareholder terhadap konservatisme akuntansi secara statistik dengan bantuan program SPSS 26 disajikan pada tabel berikut:

\section{Tabel 1. Hasil Uji Statistik Deskriptif}

Descriptive Statistics

\begin{tabular}{lrrrrr}
\hline & N & Minimum & Maximum & Mean & Std. Deviation \\
\hline Peringkat obligasi & 264 & 0 & 1 & .94 & .232 \\
Konflik Bondholder Shareholder & 264 & .256668078 & .936501676 & .68884344880 & .193040975785 \\
Konservatisme Akuntansi & 264 & -.312826199 & .134083891 & -.03843801522 & .075919152892 \\
Valid N (listwise) & 264 & & & & \\
\hline \multicolumn{1}{l}{ Sumber: Data Olahan SPSS 26 } & & & &
\end{tabular}

Sumber: Data Olahan SPSS 26

Berdasarkan Tabel 1, dapat diketahui bahwa variabel peringkat obligasi mempunyai nilai minimum sebesar 0 dan nilai maksimum 1 . Perusahaan yang dinilai 1 merupakan perusahaan yang mempunyai peringkat obligasi yang tinggi atau kategori investment grade (AAA, AA, A) dan perusahaan yang dinilai 0 merupakan perusahaan yang mempunyai peringkat di bawahnya atau kategori non investment grade (BBB, BB, B, CCC, dan D). Selain itu, nilai rata-rata peringkat obligasi perusahaan didapat sebesar 0,94 dan deviasi standar sebesar 0,232.

Konflik bondholder-shareholder mempunyai nilai minimum sebesar 0,257 yang dimiliki oleh PT Semen Indonesia Tbk pada tahun 2011 dan mempunyai nilai maksimum sebesar 0,936 yang dimiliki oleh Bank Bukopin pada tahun 2017. Selain itu, nilai rata-rata konflik bondholder-shareholder didapat sebesar 0,689 dan deviasi standar sebesar 0,913.

Konservatisme akuntansi mempunyai nilai minimum sebesar -0,313 yang dimiliki oleh PT Mitra Adiperkasa Tbk pada tahun 2012 dan mempunyai nilai maksimum sebesar 0,314 yang dimiliki oleh PT Fast Food Indonesia Tbk pada tahun 2011. Selain itu, nilai rata-rata konservatisme akuntansi didapat sebesar -0,038 dan deviasi standar sebesar 0,076.

\section{Uji Asumsi Klasik}

\section{Uji Normalitas}

Tabel 2. Hasil Uji Normalitas

One-Sample Kolmogorov-Smirnov Test

\begin{tabular}{llr}
\hline & & Unstandardized Residual \\
\hline $\mathrm{N}$ & & 245 \\
Normal Parameters ${ }^{\mathrm{a}, \mathrm{b}}$ & Mean & .0000000 \\
& Std. Deviation & .05199250 \\
Most Extreme Differences & Absolute & .055 \\
& Positive & .044 \\
& Negative & -.055
\end{tabular}



a. Test distribution is Normal.
b. Calculated from data.
c. Lilliefors Significance Correction.
Sumber: Data Olahan SPSS 26

Berdasarkan Tabel 2, dapat diketahui bahwa nilai signifikannya adalah sebesar 0,068 lebih besar dari 0,05. Dengan demikian dapat disimpulkan bahwa data terdistribusi normal dan data layak untuk diteliti.

\section{Uji Multikolinearitas}

Tabel 3. Hasil Uji Multikolinearitas

\begin{tabular}{llcc}
\hline \multicolumn{3}{c}{ Coefficients $^{\mathbf{a}}$} \\
& \multicolumn{2}{c}{ Collinearity Statistics } \\
& & Tolerance & VIF \\
\hline 1 & $\begin{array}{l}\text { Konflik Bondholder } \\
\text { Shareholder }\end{array}$ & .990 & 1.010 \\
& Peringkat obligasi & \\
a. Dependent Variable: Konservatisme Akuntansi & \\
\hline Sumber: Data Olahan SPSS 26
\end{tabular}

Sumber: Data Olahan SPSS 26

Berdasarkan Tabel 3, dapat diketahui bahwa variabel konflik bondholder-shareholder dan peringkat obligasi mempunyai nilai tolerance sebesar 0,99>0,1 dan nilai VIF sebesar 1,01 yang menunjukan variabel terbebas dari masalah multikolinearitas.

\section{Uji Heteroskedastisitas}

Tabel 4. Hasil Uji Heteroskedastisitas

Coefficients $^{\mathrm{a}}$

\begin{tabular}{llrrrrr}
\hline \multicolumn{1}{c}{ Model } & \multicolumn{2}{c}{ Unstandardized Coefficients } & Standardized Coefficients & t & Sig. \\
\cline { 2 - 8 } & B & Std. Error & Beta & & 2.916 & .004 \\
(Constant) & .038 & .013 & & -.065 & -1.014 & .311 \\
Konflik Bondholder & -.011 & .011 & & & \\
Shareholder & & & .067 & 1.039 & .300 \\
\hline
\end{tabular}

a. Dependent Variable: ABRESID

Sumber: Data Olahan SPSS 26

Berdasarkan Tabel 4, dapat diketahui bahwa nilai signifikansi variabel peringkat obligasi sebesar 0,300 dan nilai signifikan variabel konflik bondholder-shareholder sebesar 0,311. Hal ini menunjukan bahwa nilai signifikansi kedua variabel lebih dari 0,05 yang berarti tidak terjadi heteroskedastisitas.

\section{Uji Autokorelasi}

\section{Tabel 5. Hasil Uji Autokorelasi}

Model Summary ${ }^{b}$

\begin{tabular}{lrrrrr}
\hline Model & R & R Square & Adjusted R Square & Std. Error of the Estimate & \multicolumn{1}{c}{ Durbin-Watson } \\
\hline 1 & $.050^{\mathrm{a}}$ & .002 & -.006 & .05020 & 2.105 \\
\hline
\end{tabular}

a. Predictors: (Constant), Lag_X2, Lag_X1

b. Dependent Variable: Lag_Y1

Sumber: Data Olahan SPSS 26 
Berdasarkan Tabel 5, dapat diketahui bahwa hasil uji korelasi memiliki nilai DW sebesar 2,105, sedangkan diperoleh DU sebesar 1,7887. Hal tersebut menunjukan DU $<\mathrm{DW}<4$-DU atau dapat ditunjukan dengan hasil 1,7887<2,105<2,2118 yang menandakan bahwa tidak terjadi autokorelasi dalam model regresi penelitian ini.

\section{Analisis Regresi Berganda}

Analisis regresi berganda digunakan untuk mengetahui pengaruh antara dua atau lebih variabel independen terhadap variabel dependen. Pengujian model regresi linear berganda ini dilakukan dengan bantuan program SPSS 26 yang diperoleh hasil sebagai berikut:

Tabel 6. Hasil Analisis Regresi Berganda

\begin{tabular}{|c|c|c|c|c|c|c|}
\hline \multicolumn{7}{|c|}{ Coefficients $^{\mathbf{a}}$} \\
\hline \multicolumn{2}{|r|}{ Model } & \multicolumn{2}{|c|}{ Unstandardized Coefficients } & \multirow{2}{*}{$\begin{array}{c}\text { Standardized Coefficients } \\
\text { Beta } \\
\end{array}$} & \multirow{2}{*}{$\mathbf{T}$} & \multirow{2}{*}{ Sig. } \\
\hline & & B & Std. Error & & & \\
\hline \multirow[t]{4}{*}{1} & (Constant) & -.029 & 021 & & -1.422 & .156 \\
\hline & Konflik Bondholder & .020 & .017 & .075 & 1. 170 & .243 \\
\hline & Shareholder & & & & & \\
\hline & Peringkat obligasi & -.011 & 016 & -.046 & -.709 & 479 \\
\hline
\end{tabular}

a. Dependent Variable: Konservatisme Akuntansi

Sumber: Data Olahan SPSS 26

Berdasarkan hasil analisis regresi berganda pada Tabel 6, diperoleh persamaan sebagai berikut:

$$
\text { CONACC }=-0,029+0,020 \mathrm{KONF}-0,011 \mathrm{RATE}+\varepsilon
$$

Uji Hipotesis

Uji Statistik t

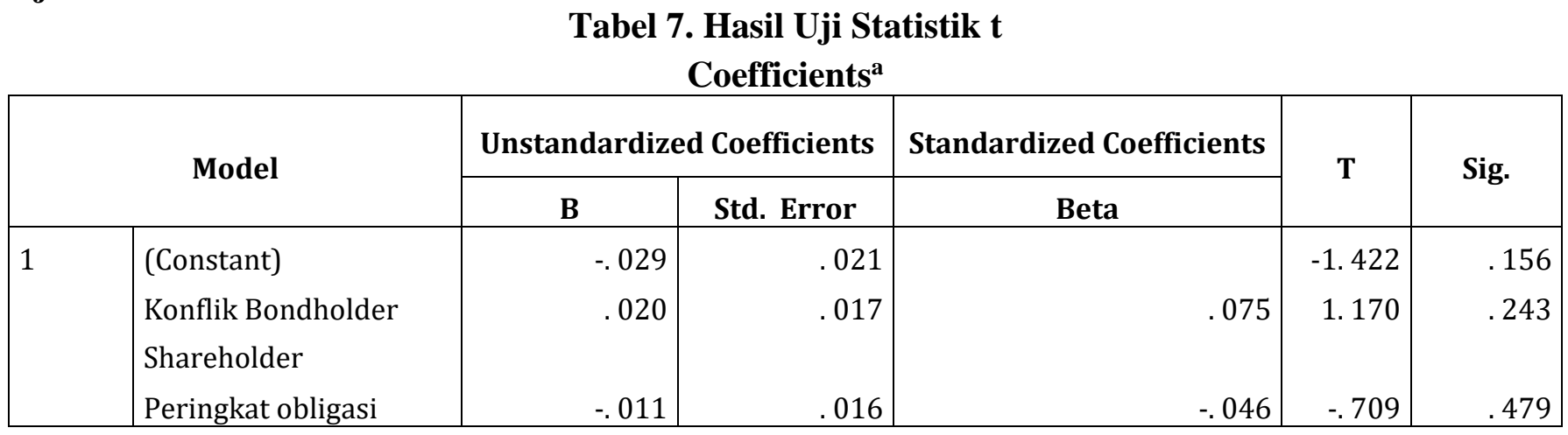

a. Dependent Variable: Konservatisme Akuntansi

Sumber: Data Olahan SPSS 26

\section{Peringkat Obligasi terhadap Penerapan Konservatisme Akuntansi}

Hipotesis pertama dalam penelitian ini yaitu peringkat obligasi berpengaruh negatif terhadap penerapan konservatisme akuntansi pada perusahaan non keuangan dan perbankan yang terdaftar di BEI tahun 20112018. Berdasarkan hasil uji statistik, variabel peringkat obligasi mempunyai nilai t hitung sebesar -0,709 lebih kecil dari t Tabel 1,7887. Selain itu, diperoleh nilai signifikansi sebesar 0,479 lebih besar dari taraf signifikansi 0,05. Hasil tersebut 40enunjukkan bahwa variabel peringkat obligasi tidak berpengaruh terhadap penerapan konservatisme akuntansi. Dengan demikian, hipotesis pertama dinyatakan tidak terdukung. 


\section{Konflik Bondholder-Shareholder terhadap Penerapan Konservatisme Akuntansi}

Hipotesis kedua dalam penelitian ini yaitu konflik bondholder-shareholder berpengaruh positif terhadap penerapan konservatisme akuntansi pada perusahaan non keuangan dan perbankan yang terdaftar di BEI tahun 2011-2018. Berdasarkan hasil uji statistik, variabel konflik bondholder-shareholder mempunyai nilai thitung sebesar 1,170 kurang dari t Tabel 1,7887. Selain itu, diperoleh nilai signifikansi sebesar 0,243 lebih besar dari taraf signifikansi 0,05. Hal tersebut 41enunjukkan bahwa variabel konflik bondholder-shareholder tidak berpengaruh terhadap penerapan konservatisme akuntansi. Dengan demikian, hipotesis kedua dinyatakan tidak terdukung.

\section{Uji Koefisien Determinasi $\left(\mathbf{R}^{2}\right)$}

\section{Tabel 8. Hasil Uji Koefisien Determinasi}

Model Summary ${ }^{b}$

\begin{tabular}{|c|c|c|c|c|}
\hline Model & $\mathbf{R}$ & R Square & Adjusted R Square & Std. Error of the Estimate \\
\hline 1 & $.092^{\mathrm{a}}$ & .008 & 000 & 052206898080 \\
\hline
\end{tabular}

a. Predictors: (Constant), Peringkat obligasi, Konflik Bondholder Shareholder

b. Dependent Variable: Konservatisme Akuntansi

Sumber: Data Olahan SPSS 26

Berdasarkan Tabel 8, dapat diketahui bahwa nilai Adjusted $R$ Square sebesar 0,000. Hal ini 41enunjukkan bahwa konservatisme akuntansi dapat dijelaskan sebesar $0 \%$ oleh variabel independen yaitu peringkat obligasi dan konflik bondholder-shareholder. Dan lainnya merupakan variasi konservatisme akuntansi dijelaskan oleh variabel-variabel diluar variabel independen dalam penelitian ini.

\section{E. SIMPULAN DAN SARAN}

\section{Simpulan}

1. Hasil uji dari hipotesis pertama 41enunjukkan bahwa peringkat obligasi tidak berpengaruh terhadap penerapan konservatisme akuntansi. Hal ini disebabkan oleh adanya rasa aman akan peringkat obligasi yang tinggi yang diraih oleh perusahaan dan kecenderungan perusahaan untuk menstabilkan laba dalam menghadapi risiko gagal bayar yang mengakibatkan perusahaan tidak menerapkan akuntansi yang konservatif.

2. Hasil uji dari hipotesis kedua 41enunjukkan bahwa konflik bondholder-shareholder tidak berpengaruh terhadap penerapan konservatisme akuntansi. Hal ini disebabkan oleh minimnya konflik bondholdershareholder suatu perusahaan tidak memengaruhi penerapan akuntansi yang konservatif.

\section{Saran}

1. Menambah atau mengganti variabel independen yang digunakan dengan yang memiliki pengaruh lebih tinggi ke variabel dependen.

2. Menggunakan atau menambah perusahaan yang terperingkat oleh lembaga pemeringkat obligasi selain Pefindo, seperti Moody's Investor Services dan Standard and Poor's Corporation.

\section{REFERENSI}

Adhiputra, M. W. , dan Astika, I. B. (2018). Pengaruh Penerapan Konservatisme Akuntansi dan Tingkat Kepemilikan pada Konflik Bondholder-Shareholder di Bursa Efek Indonesia. Jurnal Ekonomi dan Bisnis

Chan, A. L. , dan Lin, S. W. (2009). Accounting Conservatism and The Cost of Equity Capital: UK Evidence. Jurnal Akuntansi

Fahmi, I. (2014). Manajemen Keuangan Perusahaan dan Pasar Modal. Jakarta: Mitra Wacana Media 
Fahmi, I. (2013). Pengantar Pasar Modal. Bandung: Alfabeta

Ghozali, I. (2016). Aplikasi Analisis Multivariete dengan Program IBM SPSS 23. Semarang: Badan Penerbit Universitas Diponegoro

Givoly, D. , dan Hayn, C. (2000). The Changing Timeliness-Series Properties of Earnings, Cash Flow and Accrual: Has Financial Accounting Become More Conservative? Jurnal Akuntansi dan Ekonomi

Graham, A. , dan Maher, J. J. (2015). Environmental Liabilities, Bond Ratings, and Bond Yields. Jurnal Akuntansi Hermawan, A. (2009). Penelitian Bisnis Paradigma Kuantitatif. Jakarta: PT Grasindo

Jensen, M. C. , dan Meckling, W. H. (1976). Theory of the Firm: Managerial Behavior, Agency Cost, and Ownership Structure. Journal of Financial Economics

Kompas. (2019). Kasus Perusahaan Tekstil Terbesar Gagal Bayar Bunga Obligasi, Ini Kata Bos BCA. Retrieved Agustus 30, 2019, from money. Kompas. Com: https://money. Kompas. Com/read/2019/07/24/211100326/kasus-perusahaan-tekstil-terbesar-gagal-bayar-bunga-obligasi-ini-katabos-bca?page=all

Kompas. (2019). Rhenald Kasali: Tiap Kondisi Keuangan Membaik, Garuda Selalu Heboh. Retrieved Agustus 30, 2019, from money. Kompas. Com: https://money. Kompas. Com/read/2019/04/30/125132726/rhenaldkhasali-tiap-kondisi-keuangan-membaik-garuda-selalu-heboh?page=all

Lukviarman, N. (2016). Corporate Governance. Solo: PT Era Adicitra Intermedia

Narandika, H. M. , Sanusi, F. , dan Utami, I. (2016). Pengaruh Rasio Profitabilitas dan Rasio Leverage terhadap Peringkat Obligasi (Studi Empiris pada Perusahaan Sub Sektor Perbankan yang Terdaftar di Bursa Efek Indonesia Periode 2010-2015). Jurnal Manajemen dan Bisnis

Nasih, M. , dan Hudaya, R. (2011). Konservatisme Akuntansi dan Konflik Bondholder-Shareholder pada Perusahaan Non Keuangan Terdaftar di Bursa Efek Indonesia. Jurnal Akuntansi dan Manajemen

Novita, M. (2017). Pengaruh Konflik Bondholder-Shareholder, Bonus Plan dan Political Cost terhadap Konservatisme Akuntansi. Jurnal Akuntansi

Pramudita, N. (2012). Pengaruh Tingkat Kesulitan Keuangan dan Tingkat Hutang terhadap Konservatisme Akuntansi pada Perusahaan Manufaktur di BEI. Jurnal Akuntansi

Priyastama, R. (2017). Buku Sakti Kuasai SPSS. Yogyakarta: Start Up

Sari, C. , dan Andhariani, D. (2009). Konservatisme Perusahaan di Indonesia dan Faktor-Faktor yang Memengaruhinya. Simposium Nasional Akuntansi 12 Palembang

Sari, D. (2004). Hubungan antara Konservatisme Akuntansi dengan Konflik Bondholders-Shareholders Seputar Kebijakan Dividen dan Peringkat Obligasi. Jurnal Akuntansi dan Keuangan Indonesia

Sari, R. C. , dan Zuhrohtun. (2006). Keinformatifan Laba di Pasar Obligasi dan Saham: Uji Liquidation Option Hypothesis . Simposium Nasional Akuntansi IX Padang

Sarwono, J. (2017). Mengenal Prosedur-Prosedur Populer dalam SPSS 23. Jakarta: PT Elex Media Komputindo

Savitri, E. (2016). Konservatisme Akuntansi. Yogyakarta: Pustaka Sahila Yogyakarta

Septyawanti, H. I. (2013). Faktor-Faktor yang Memengaruhi Peringkat Obligasi. Jurnal Akuntansi

Suryandari, E. , dan Priyanto, R. E. (2012). Pengaruh Risiko Ligitasi dan Tingkat Kesulitan Keuangan Perusahaan terhadap Hubungan antara Konflik Kepentingan dan Konservatisme Akuntansi. Jurnal akuntansi dan Investasi

Susanto, T. S. , Sutejo, B. S. , dan Marciano, D. (2012). Pengaruh Kinerja Keuangan Bank terhadap Rating Obligasi Bank di Indonesia. Jurnal Manajemen Teori dan Terapan

Ulfa, M. , Diana, N. , dan Mawardi, M. (2018). Pengaruh Konflik Bondholder-Shareholder, Bonus Plan dan Political Cost terhadap Konservatisme Akuntansi. Jurnal Akuntansi

Veronica, A. (2015). Faktor-Faktor yang Memengaruhi Peringkat Obligasi pada Perusahaan Manufaktur. Jurnal Manajemen dan Bisnis

Watts, R. L. (2003). Conservatism in Accounting Part I: Explainations and Implications. Journal Accounting and Economics

Widarjono, A. (2017). Ekonometrika. Yogyakarta: UPP STIM YKPN

Xu, X. , Wang, X. , dan Han, N. (2012). Accounting Conservatism, Ultimate Ownership and Investment Efficiency. Jurnal Akuntansi. 